Kiss Gábor írása méltó lezárása a kötetnek, mely programot ad a geomorfológiai értékek védelméhez. A földrajzi érték fogalmának meghatározása nyomán lehetövé válik az ilyen értelemben értékes tájelemek kiválasztása, majd a szerzö által javasolt kritériumrendszer szerint az egyes elemek értékmeghatározása (ritkaság, típusosság). $\mathrm{Az}$ értékek megörzése szempontjából - a szerzővel egyetértve - a törvényi védelemmel legalább egyenértékủnek érzem a tudatformálást, melyet a tanár kollégák akár órán, akár azon kívül nap mint nap gyakorolhatnak. A tanulmány erössége, hogy a módszer használhatóságát konkrét természeti tájon mutatja be. Kivánjuk, hogy mihamarabb további tájakra is elvégezzék ezt a munkát!

A kötet egészét jó szívvel ajánlom minden gyakorló tanárnak, sőt az érdeklödö diákoknak is. Remélem, hogy a sorozat ezután is értékes írásokat összefogó kötetekkel jelentkezik majd a földrajz lényeges kérdéseiröl.

Nagy Gábor

\title{
A TERÜLET MARKETINGJE. A VÁROSOK, ÁLLAMOK, NEMZETEK BERUHÁZÁSI, IPARI ES IDEGENFORGALMI VONZEREJE
}

\author{
P. Kotler-D. H. Haider-I. Rein (1993) Marketing Places. Attracting \\ Investment, Industry, and Tourism to Cities, States, and Nations. \\ The Free Press, New York, 388 o.
}

Napjainkban a gazdasági folyóiratokban egyre gyakrabban lehet találkozni olyan hirdetésekkel, amelyek nem egy terméket állítanak a középpontba, hanem egy hely (város, megye, ország) kedvezö adottságaira igyekeznek felhívni az olvasók mint potenciális vásárlók figyelmét. Ez a tevékenység azonban csak egy apró - talán a leglátványosabb - jele annak a változásnak, amely a területi és településpolitikában az elmúlt 10-15 évben Nyugat-Európában és Észak-Amerikában végbement, és amelynek egyre több jele mutatkozik hazánkban is: az egyes helyeknek meg kell jelenniük a piacon, és a kereskedelmi fogalomba kerülő árucikkekhez hasonlóan el kell adniuk saját magukat.

Az ezen a területen eddig felhalmozódott ismereteket próbálja meg ósszefoglalni a modern marketingtudomány egyik legjelentősebb alakja - Philip Kotler - és két társa által írt könyv. A világos szerkezettel rendelkezó mü előnyei közé lehet sorolni, hogy nemcsak a témakör elméleti kérdéseivel foglalkozik, hanem az egész világból hozott példák segítségével a gyakorlatban is bemutatja az újfajta politika különbözö oldalait. (Külön érdekesség, hogy a könyvben - sajnos negativ megközelítésben - Magyarország is megemlítésre kerül.) 
$\mathrm{Az}$ elsö két fejezetben (,Places in Trouble", "How Places Market Themselves") a szerzők általános elemzést adnak az egész problémakörröl. Feitárják mindazokat a külső és beiső okokat (pl. a globális világgazdaság kialakulása, a gyors technológiai fejlỏdés, a kormányzati politika megváltozása), amelyek elöidézik az egyes helyek válságát és bemutatják, hogy eddig milyen lépések tơrténtek a felmerült problémák leküzdése érdekében. Rövid áttekintést adnak azokról a csoportokról (pl. turisták, üzletemberek, potenciális lakosok), akik számára elönyösek lehetnek az egyes helyek által kínált adottságok, valamint javaslatokat fogalmaznak meg a jövöbeli tennivalókkal kapcsolatban.

A sikeres marketing alapvetö feltétele a vásárláshoz vezető út pontos ismerete, ennek következtében egyáltalán nem meglepö, hogy a harmadik fejezet (,,How Target Markets Make Their Choices") ezzel a témakörrel foglalkozik. A vásárlási folyamatot öt szakaszra bontják a szerzök (problémaészlelés, információgyüjtés, a felmerült alternatív lehetőségek értékelése, vásáriási döntés, vásárlás utáni viselkedés), és bemutatják az egyes szakaszok néhány jellegzetes sajátosságát, a potenciális vevök viselkedését befolyásoló tényezöket, valamint azt, miként tudják az egyes helyek kedvezöen befolyásolni a végsö dőntést.

$\mathrm{Az}$ egyes helyek marketingmunkájával kapcsolatban a legtöbb ember csak a reklámozásra gondol. Ezzel a téves felfogással kíván leszámolni a következö két fejezet (., The Place Auditing and Strategic Market Planning Process", „Strategies for Place Improvement"), rávilágítva azokra a tevékenységekre, amelyek szintén a marketingfolyamat szerves részét alkotják.
$\mathrm{Az}$ egyik lényeges feladat egy több lépcsőböl álló stratégiai-fejlesztési program kialakitása. Ennek keretében elöször fel kell tárni az illető hely és vetélytársai legfontosabb adottságait, valamint az általános fejlödési trendeket, majd erre támaszkodva el kell végezni az ún. SWOT-elemzést (strengths, weaknesses, opportunities, threats).

Ezek a vizsgálatok világos és áttekinthető képet adnak az adott hely elönyeiröl, és lehetővé teszik néhány olyan terület kijelölését, ahol jók a lehetőségek a kitörésre. A harmadik lépcsőben ki kell dolgozni egy az elképzeléseket végleges formába öntő akciótervet, majd a végrehajtás során célszerú állandóan összevetni a célokat és az elért eredményeket.

Ezzel párhuzamosan lépéseket kell tenni a megfelelö feltételek kialakítása érdekében, amely több területet is magába foglal. Egyrészt szükséges egy olyan városi arculat (,urban design") létrehozása, amely feltámasztja a település korábbi szellemét és mind a lakosság, mind a látogatók igényeit kielégítỏ környezetet teremt.

Másrészt a fejlödés alapvető feltétele a város által betölteni kívánt szerep ellátásához nélkülözhetetien anyagi és szellemi infrastruktúra megteremtése. Ez átfogja a víz- és szennyvízhálózat bövítését, a közlekedés (azon belül is elsösorban a környezetbarát megoldások) fejlesztését, a nagyobb városok esetében repülioterek, magasabb komfortfokozatú szállodák, elökelö éttermek és kongresszusi központok megépítését. Igen fontos a város marketingtevékenységében résztvevő emberek (pl. önkormányzati alkalmazottak) állandó továbbképzése, valamint a város lakosságának körében annak tudatosítása, hogy ven- 
dégszeretetük, a látogatókhoz való viszonyuk jelentősen befolyásolja településük sorsát.

Harmadrészt létfontosságú olyan látványosságok kialakitása, amelyek a látogatók nagy tömegei számára jelentenek vonzeröt. Ezek köre igen széles, és - többek között magukba foglalják a természeti adottságokat (pl. kanyonok, gyógyitó hatású termálviz), történelmi emlékhelyeket, kulturális és sporteseményeket stb.

A marketingröl a legtöbb embernek a reklámozás, egy kedvezỏ imázs (image) kialakitására és hatékony szállitására irányuló törekvés jut az eszébe, és ennek fényében érthetö, hogy a hatodik és hetedik fejezet (,Designing the Place's Image", "Distributing the Place's Image and Messages") ezt a kérdéskört járja körül. A szerzők mindenekelött egy rövid, de igen frappáns definíciót adnak a napjainkban egyre gyakrabban használt fogalomra (imázs: egy adott helyröl az emberek fejében kialakult elképzelések és benyomások összessége), majd feltárják a létezö imázst befolyásoló tényezöket. Megfogalmazzák azokat a feltételeket, amelyeknek egy hatékony imázs megteremtésekor teljesülniük kell (legyen igaz, egyszerü, hihető, megkülönböztetö, rendelkezzen vonzerövel). Bemutatják az imázs terjesztése során felhasználható különbözö eszközöket (pl. rádió-, televízió- és újsághirdetések), elemzik az egyes módszerek elönyeit, illetve hátrányait és meghatározzák azokat a tényezőket, amelyek elösegitik a különböző reklámlehetöségek közötti döntést.

A következő négy fejezet már konkrét célcsoportokkal foglalkozik és arról ad áttekintést, hogyan tudnak ezek körében az egyes helyek sikeres marketingmunkát végezni. A nyolcadik fejezet (,,Attracting the Tourism and Hospitality Business Markets") elsósorban a turizmusra koncentrál. Rávilágít az egyes helyek életében betöltött szerepének fontosságára, kiemeli a szakszerü piacszegmentáció jelentőségét, és példákkal alátámasztva bemutat néhány olyan módszert (pl. a múlt feltámasztása, eseménybázisú turizmus), amelyek jó lehetőséget kínálnak az idegenforgalom fejlesztésére.

Napjainkban a legtöbb ország és város helyzete még szoros kapcsolatban áll a helyi ipar fejlettségi fokával, ezért a szerzők a következö két fejezetben (.,Attracting, Retaining, Expanding, and Starting Businesses”, „Expanding Exports and Stimulating Foreign Investment") ezzel a témakörrel foglalkoznak. Felsorolják azokat az eszközöket, amelyeket a helyek felhasználhatnak a multinacionális vállalatok új telephelyeinek, a cégek irodáinak vonzása érdekében, másrészt azonban hangsúlyozzák azt is, hogy az egyes államoknak, településeknek támogatniuk kell az új cégek indulását is, és elö kell segiteniük részvételüket a különböző nemzetközi kiállitásokon és vásárokon, betörésüket a külfôldi piacokra.

A nyugati világban - azon belül is elsösorban az Amerikai Egyesült Államokban a területi politika egyre nagyobb figyelmet fordít egyes társadalmi csoportok csábítására (pl. nyugdíjasok, magasan képzett rétegek), illetve távoltartására (pl. alacsony képzettségü bevándorlók, bünözők). A tizenegyedik fejezet (,Attracing Residents") feltárja ezen politika fontosságát, elemzi a népszerü és népszerütlen rétegek jellemvonásait, és bemutatja 
azokat a lépéseket, amelyeket az egyes helyek az eddigiekben ezen a területen tettek.

Az utolsó fejezetben (,,Organizing for Change") a szerzők egy általános áttekintést adnak a marketingfolyamat egészéröl. Rámutatnak azokra a kihívásokra, amelyek elöidézték a változást a területi politikában, és röviden összefoglalják mindazokat a kínálkozó válaszlépéseket, amelyek lehetövé teszik az új körülményekhez történö alkalmazkodást.

Kozma Gábor

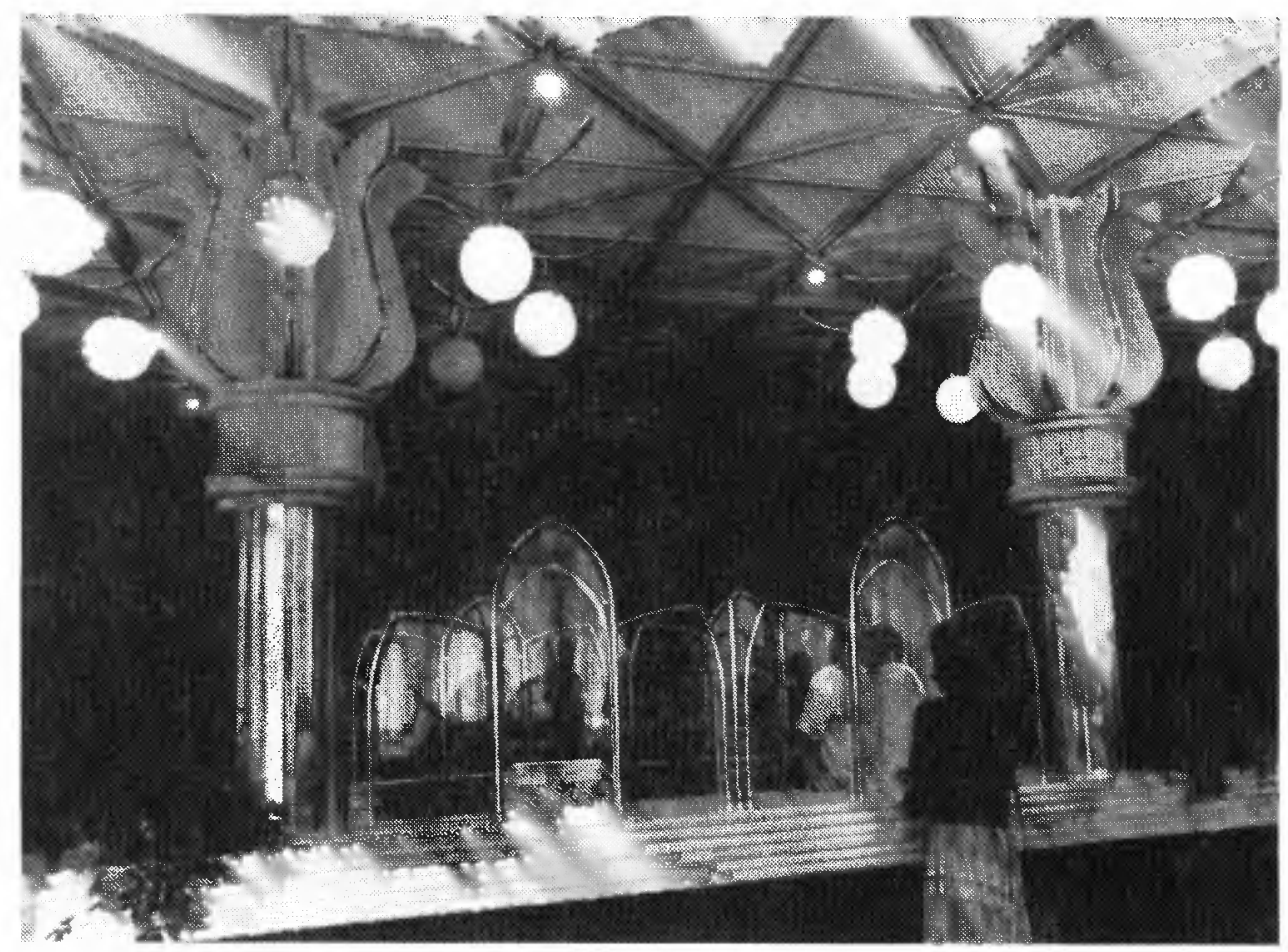

Bankház Szombathelyen (MTI FOTÓ - Czika László) 